УДК 911.9

DOI 10.18413/2712-7443-2020-44-1-41-54

\title{
Об изменении исчисления времени в регионе Европейской России (на примере Чувашской Республики)
}

\section{Ю.Р. Архипов, И.В. Никонорова, Н.А. Казаков, Н.Г. Караганова}

Чувашский государственный университет имени И.Н. Ульянова, Россия, Чувашская Республика, 428015, г. Чебоксары, Московский проспект, 15

E-mail: yurarkhipov@mail.ru,niko-inna@yandex.ru,kzkv75@mail.ru, amazonka1@rambler.ru

\begin{abstract}
Аннотация. Рассмотрены предпосылки и последствия изменения часовой зоны с МСК на МСК +1 на примере Чувашской Республики - региона, расположенного на востоке Европейской территории России (ЕТР). Реформа часовых зон в стране в 2011-2014 гг. по сей день неоднозначно воспринимается в регионах. Авторы проводят анализ географических, физиологических факторов и современной социально-экономической ситуации в Чувашской Республике и соседних регионах, а также возможных изменений в аспекте влияния смены часовой зоны. Рассчитаны прогнозные потери и приращения светового дня в зимний и летний периоды, как следствие, потери или экономия энергии, в особенности для сферы образования. Дана попытка сопоставить динамику дорожно-транспортных происшествий и уличных преступлений в аспекте влияния смены часовой зоны и сравнить ее с показателями в соседних регионах ЕТР. Результаты исследования могут быть использованы органами государственной власти, а также иными лицами при принятии решений, связанных с управлением в регионе.
\end{abstract}

Ключевые слова: Чувашская Республика, оптимизация времяисчисления, часовая зона, истинный полдень, местное время, изменения периодов бодрствования, потери и экономия энергии.

Для цитирования: Архипов Ю.Р., Никонорова И.В., Казаков Н.А., Караганова Н.Г. 2020. Об изменении исчисления времени в регионе Европейской России (на примере Чувашской Республики). Региональные геосистемы, 44(1): 41-54. DOI:10.18413/2712-7443-2020-44-1-41-54

\section{On change of calculation of time in the region of European Russia (on the example of the Chuvash Republic)}

\author{
Yury R. Arkhipov, Inna V. Nikonorova, Nikolay A. Kazakov, Natalia G. Karaganova \\ Chuvash State University, \\ 15 Moskovsky Prospect, Cheboksary, 428015, Chuvash Republic, Russia
}

E-mail: yurarkhipov@mail.ru,niko-inna@yandex.ru,kzkv75@mail.ru, amazonka1@rambler.ru

\begin{abstract}
Reform of time zones in Russian Federation in 2011-2014 is ambiguously perceived in the regions to this day. The article discusses the prerequisites and consequences of changing the time zone from MSC to MSC + 1 using the example of the Chuvash Republic - a region located in the east of the European territory of Russia (ETR). The question of the transition of Chuvashia from second to the third time zone remains open. The authors analyze the geographical, physiological factors and the current socio-economic situation in the Chuvash Republic and neighboring regions, as well as possible changes in the aspect of the impact of changing the time zone. The article calculates the predicted losses and
\end{abstract}


increments of daylight hours in the winter and summer periods, as a result, losses or energy savings, especially for the education sector. An attempt is made to compare the dynamics of traffic accidents and street crimes in terms of the impact of changing the time zone and compare it with the results in the neighboring regions of the ETR. The results of this article can be used by state authorities, as well as by other persons in making decisions related to management in the region. The ETR regions, which have moved into the MSC +1 zone, have received some positive advantages. However, for Chuvashia it is impossible to draw such unambiguous conclusions.

Keywords: Chuvash Republic, time calculation optimization, time zone, true noon, local time, changing of wakeful periods, loss and energy saving.

For citation: Arkhipov Yu.R., Nikonorova I.V., Kazakov N.A., Karaganova N.G. 2020. On change of calculation of time in the region of European Russia (on the example of the Chuvash Republic). Regional Geosystems, 44(1): 41-54. DOI: 10.18413/2712-7443-2020-44-1-41-54

\section{Введение}

С 7 августа 2011 года в Российской Федерации вступил в силу закон «Об исчислении времени». В нём было введено понятие часовая зона - «...часть территории Российской Федерации, на которой действует единое время, установленное Правительством Российской Федерации...» [Об исчислении времени, 2011]. «...Решение о переводе территории (части территории) субъекта Российской Федерации из одной часовой зоны в другую часовую зону принимается Правительством Российской Федерации на основании совместного предложения законодательного (представительного) органа государственной власти субъекта Российской Федерации и высшего должностного лица субъекта Российской Федерации (руководителя высшего исполнительного органа государственной власти субъекта Российской Федерации)...» [Об исчислении времени, 2011]. В след за законом последовало постановление Правительства Российской Федерации «О составе территорий, образующих каждую часовую зону, и порядке исчисления времени в часовых зонах ...» [2011]. Согласно данному постановлению московская часовая зона была определена в отношении всемирного координированного времени и национальной шкале времени Российской Федерации как UTC (SU) + 4 часа, сезонный перевод часов (на зимнее и летнее время) отменялся, а регионы европейской России были разделены между тремя часовыми зонами. В первой часовой зоне (московское время минус один час) оказалась Калининградская область, в третьей часовой зоне (московское время плюс 2 часа) - Республика Башкортостан, Пермский край, Оренбургская область, все остальные регионы образовали вторую часовую зону и стали (продолжили) жить по московскому времени. Всего было образовано 9 часовых зон [О составе территорий ..., 2011].

21.07.2014 была принята первая редакция Федерального Закона «Об исчислении времени». Московское время, являющееся основой для исчисления местного времени в часовых зонах, теперь стало соответствовать третьему часовому поясу в национальной шкале времени Российской Федерации UTC (SU) + 3, число часовых зон возросло до 11, Республика Башкортостан, Пермский край, Оренбургская область $(\mathrm{MCK}+2)$ с Курганской, Свердловской, Тюменской, Челябинской областями, Ханты-Мансийским автономным округом - Югра и Ямало-Ненецким автономным округом составили 4 часовую зону, а Удмуртская Республика и Самарская область, в 2011-2014 гг. жившие по московскому времени, образовали третью часовую зону - плюс один час к московскому времени $(\mathrm{MCK}+1)$. В последующем в третью часовую зону $(\mathrm{MCK}+1)$ перешли Астраханская и Ульяновская области (редакция ФЗ «Об исчислении времени» от 09.03.2016), Саратовская область (от 22.11.2016), Волгоградская область (от 11.10.2018) [Об исчислении времени, 2011]. Был поднят вопрос о присоединении к третьей часовой зоне и в Чувашской Республике. Появились инициативные группы, отстаивающие в средствах массовой информации, особенно в сети Интернет, и властных кабинетах республики идею перевода стрелок на 
час вперёд. Проводились интернет опросы граждан, но они не дали, да и не могли дать результат, который можно было бы счесть репрезентативным. На организацию изучения особенностей использования времени в сутках населением Чувашии и проведение репрезентативного социологического опроса средств в бюджете республики не нашлось. Вопрос о переходе Чувашии в третью часовую зону остаётся открытым. Попытаемся взвесить аргументы «за» и «против» данного перехода.

\section{Объекты исследования}

Времяисчисление тесно связано с понятием «истинный (солнечный) полдень»моментом верхней кульминации Солнца, когда для наблюдателя в данной точке планеты центр солнечного диска проходит через небесный меридиан, и достигается максимальное возвышение солнца относительно горизонта [Kotlyakov, Komarova, 2007]. По причине того, что Земля движется вокруг Солнца по эллиптической орбите, солнечные сутки между двумя солнечными полуднями, в течение года меняются. На этот эффект накладывается другой, связанный с наклоном оси вращения Земли (рис. 1).

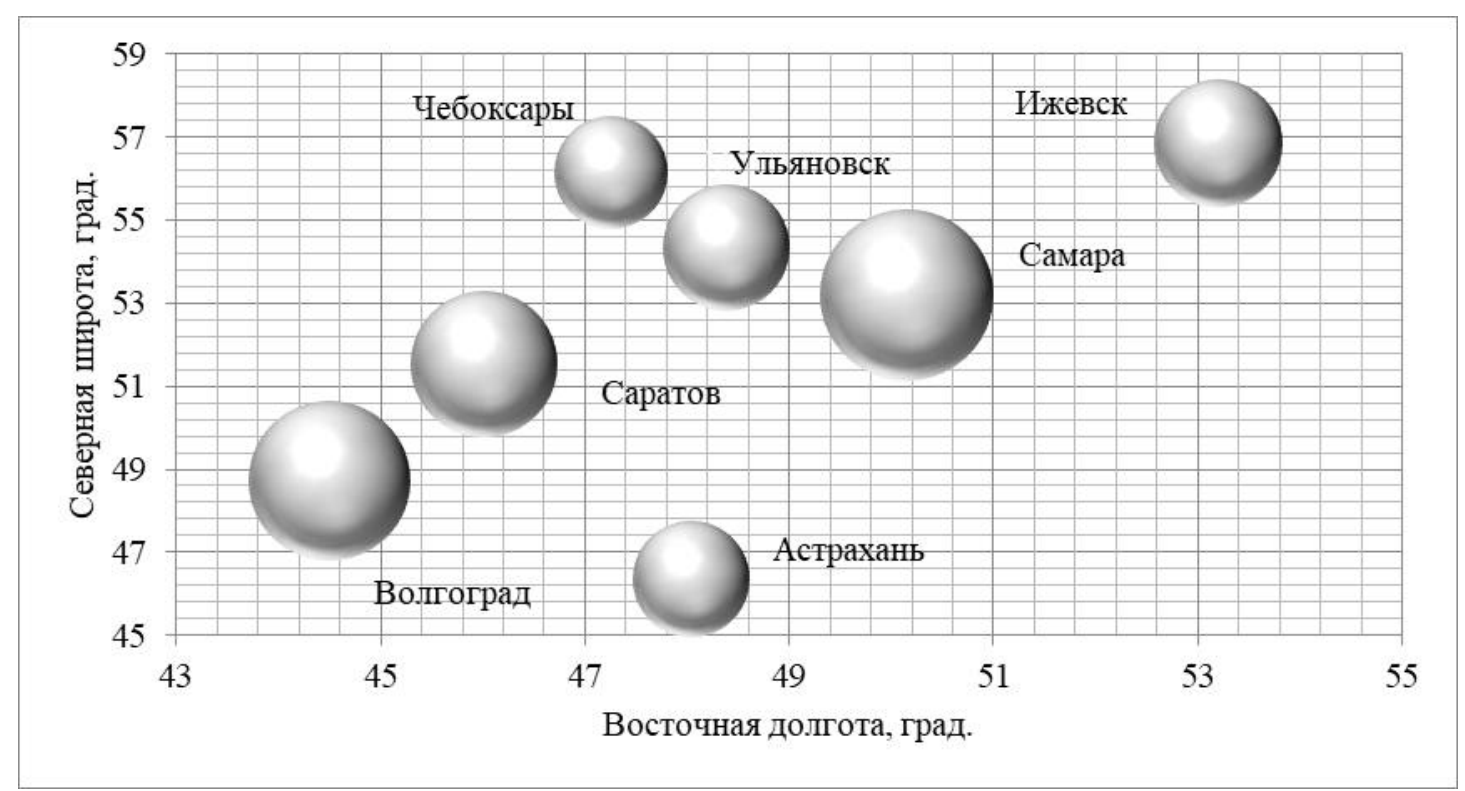

Рис. 1. Схематичное расположение «столиц» (центров) регионов, живущих по времени МСК +1 и столицы Чувашской Республики относительно друг друга в географической системе координат Fig. 1. Schematic arrangement of the "capitals" (centers) of the regions living by the time MSC +1 and the capital of the Chuvash Republic relative to each other in a geographical coordinate system

Считается, что чем ближе «истинный полдень» к полдню по местному времени (12.00), тем условно «точнее» местное время. Если исходить из этого постулата, то почти все регионы, образовавшие третью часовую зону, пожертвовали «точностью» местного времени, особенно самые западные - Волгоградская и Саратовская области. Если до перехода в зону МСК +1 среднеквадратичное отклонение истинного полдня от полдня по местному времени в них составляло 0,148 и 0,164, то теперь достигает 1,035 и 0,936 соответственно. В случае перехода Чувашии в третью часовую зону её также ждёт существенное возрастание расхождения полдня по местному времени со временем наступления «истинного полдня», среднеквадратичное отклонение возрастёт с 0,216 до 0,917.

Исключение среди регионов зоны МСК+1 составляет Удмуртская Республика. Если бы в Удмуртии было принято решение о сохранении московского времени, то среднеквадратичное отклонение полдня по местному времени с временем наступления «истинного полдня» возросло с 0,468 до 0,574 (рис. 2). 


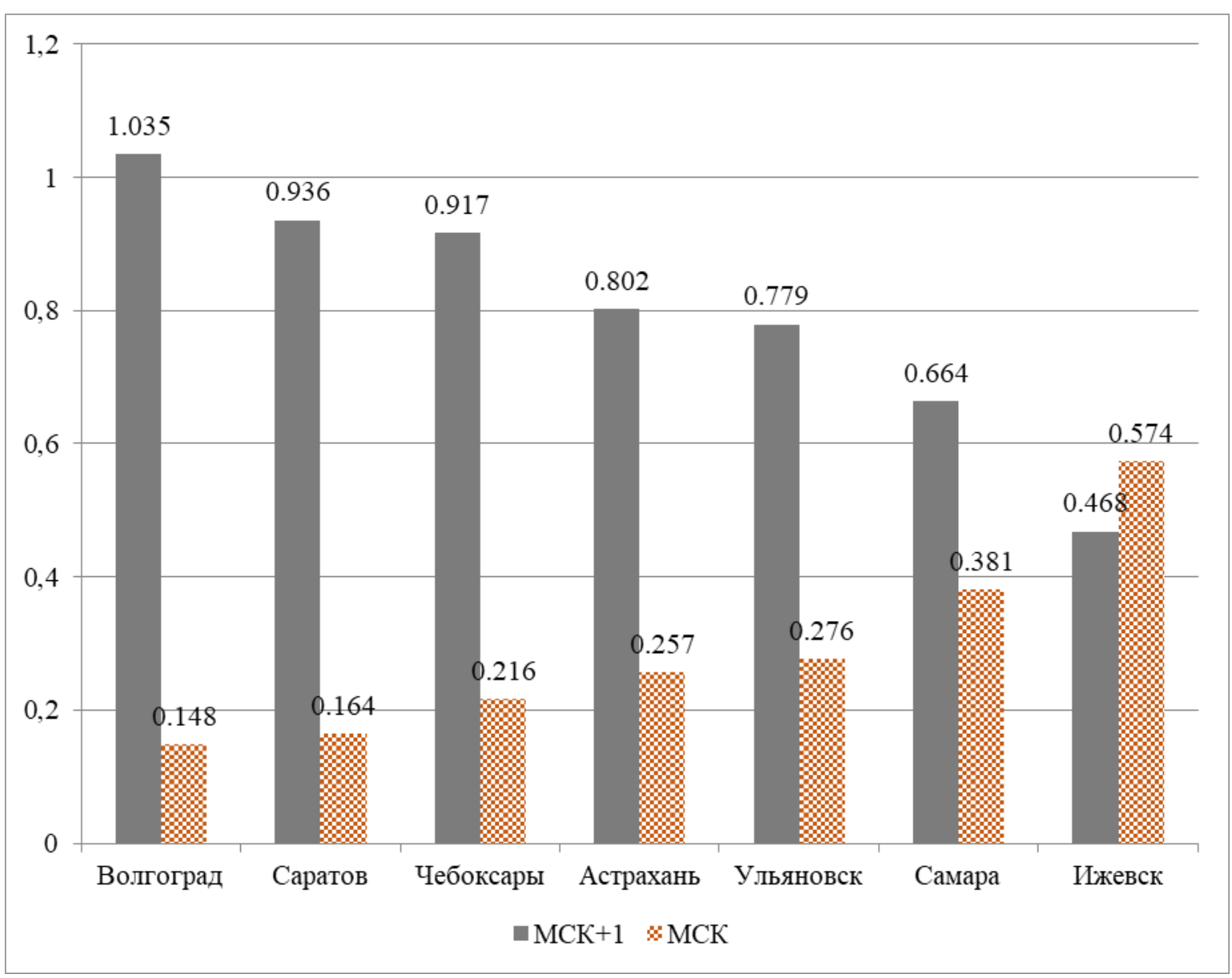

Рис. 2. Среднеквадратичное отклонение времени наступления истинного полдня от полдня по местному времени при МСК и МСК +1 Fig. 2. The standard deviation of the time of occurrence of true noon from noon local time for MSC and MSC +1

Казалось бы, исходя из соотношения полдня по местному времени и времени наступления «истинного полдня» единственным регионом в третьей часовой зоне должна быть Удмуртская Республика, но «точность» не всегда удобна и выгодна.

Перевод стрелок на час вперёд позволяет скорректировать границы светового дня с границами времени бодрствования людей (подъёмом, отходом ко сну). Для этого некогда и вводились «декретное», «летнее», «зимнее» время [Звоновский, 2010; Ермолаев, 2016]. Поэтому необходимо иметь представление о структуре населения по использованию им времени в сутках, особенно работающего и учащегося. К сожалению, в отношении населения Чувашии таких исследований не проводилось [Алексеев и др., 2012]. У работающего и учащегося населения время бодрствования в будни во многом определяется временем начала работы, учёбы. Поэтому, зная возрастную структуру населения, структуру населения по видам деятельности (в том числе экономической), группам занятости на основной работе, можно предположить, хотя и довольно приблизительно, в какое время большинство людей в регионе начинают свой трудовой день.

\section{Результаты и обсуждение}

Исходя из структуры населения Чувашии по видам деятельности (табл. 1), допустим вывод, что около 80 \% работающего и учащегося населения республики, начинает свой трудовой день не позднее 8.00. А значит, и вставать они должны, с учётом времени на утренний туалет и дорогу до места работы, учёбы, не позднее 5-7 часов утра. В крупных локальных системах расселения (городских агломерациях) время на дорогу из дома 
до работы нередко достигает и даже превышает значение в 1,5 часа. Соответственно время отхода ко сну при реализации программы относительно полноценного отдыха (не менее 7 часов на сон) должно быть не позднее 22-24 часов. То есть период бодрствования может быть определён в среднем как временной интервал с 6.00 до 23.00. Однако следует задать вопрос: в течение всего ли времени бодрствования человеку необходим солнечный свет? Считают, что для довольно большой группы людей солнечный свет является стимулом к пробуждению и одновременно мешает засыпанию (свет подавляет выработку мелатонина) [Цфасман и др., 2013; Звягина, Диогенова, 2018]. Если человек отходит ко сну около 23.00, то после 22.00 солнечный свет ему по сути уже не нужен, а вот пробуждаться желательно при солнечном свете. Таким образом, период бодрствования среднестатистического работающего или учащегося в течение суток - это временной промежуток с 6.00 до $22.00-23.00$.

Таблица 1

Table 1

Состав и структура населения Чувашской Республики по видам деятельности (2018) ${ }^{1}$

Composition and structure of the population of the Chuvash Republic by type of activity (2018)

\begin{tabular}{|c|c|c|}
\hline Вид деятельности & $\begin{array}{c}\text { тыс. } \\
\text { человек }\end{array}$ & $\begin{array}{c}\text { Доля от числа } \\
\text { обучающихся } \\
\text { и работающих, } \\
\% \\
\end{array}$ \\
\hline Всего обучающихся & 199,457 & 25,32 \\
\hline $\begin{array}{l}\text { Число обучающихся в общеобразовательных учебных заведениях } \\
\text { в } 2018-2019 \text { учебном году }\end{array}$ & 137,858 & 17,50 \\
\hline Число обучающихся в организациях СПО & 24,820 & 3,15 \\
\hline Число обучающихся в организациях ВО & 36,779 & 4,67 \\
\hline Всего занято в экономике & 588,3 & 74,68 \\
\hline Руководители & 55,2 & 7,01 \\
\hline Специалисты высшего уровня квалификации & 101,4 & 12,87 \\
\hline Специалисты среднего уровня квалификации & 57,0 & 7,24 \\
\hline $\begin{array}{l}\text { Служащие, занятые подготовкой и оформлением документации, } \\
\text { учетом и обслуживанием }\end{array}$ & 11,6 & 1,47 \\
\hline $\begin{array}{l}\text { Работники сферы обслуживания и торговли, охраны граждан и } \\
\text { собственности }\end{array}$ & 94,7 & 12,02 \\
\hline $\begin{array}{l}\text { Квалифицированные работники сельского и лесного хозяйства, } \\
\text { рыбоводства и рыболовства }\end{array}$ & 22,5 & 2,86 \\
\hline $\begin{array}{l}\text { Квалифицированные рабочие промышленности, строительства, } \\
\text { транспорта и рабочие родственных занятий }\end{array}$ & 116,1 & 14,74 \\
\hline $\begin{array}{l}\text { Операторы производственных установок и машин, сборщики } \\
\text { и водители }\end{array}$ & 61,0 & 7,74 \\
\hline Неквалифицированные рабочие & 68,8 & 8,73 \\
\hline Итого & 787,757 & 100 \\
\hline
\end{tabular}

1 Занятое население Чувашской Республики в возрасте 15 лет и старше по полу и группам занятий на основной работе (2017-2018). Электронный ресурc. URL: http://chuvash.gks.ru/wps/wcm /connect/rosstat_ts/chuvash/ru/statistics/employment/ (дата обращения: 19 августа 2019). 
Регионы, отказавшиеся от московского времени и составившие к 2019 году зону $\mathrm{MCK}+1$, получили в период суточного бодрствования людей дополнительно в год от 156,73 (Волгоградская область) до 195,43 часов (Удмуртская Республика) светового времени. Присоединение Чувашской Республики к зоне МСК +1 добавит её населению в период суточного бодрствования 174,62 часа светового времени в год (рис. 3).

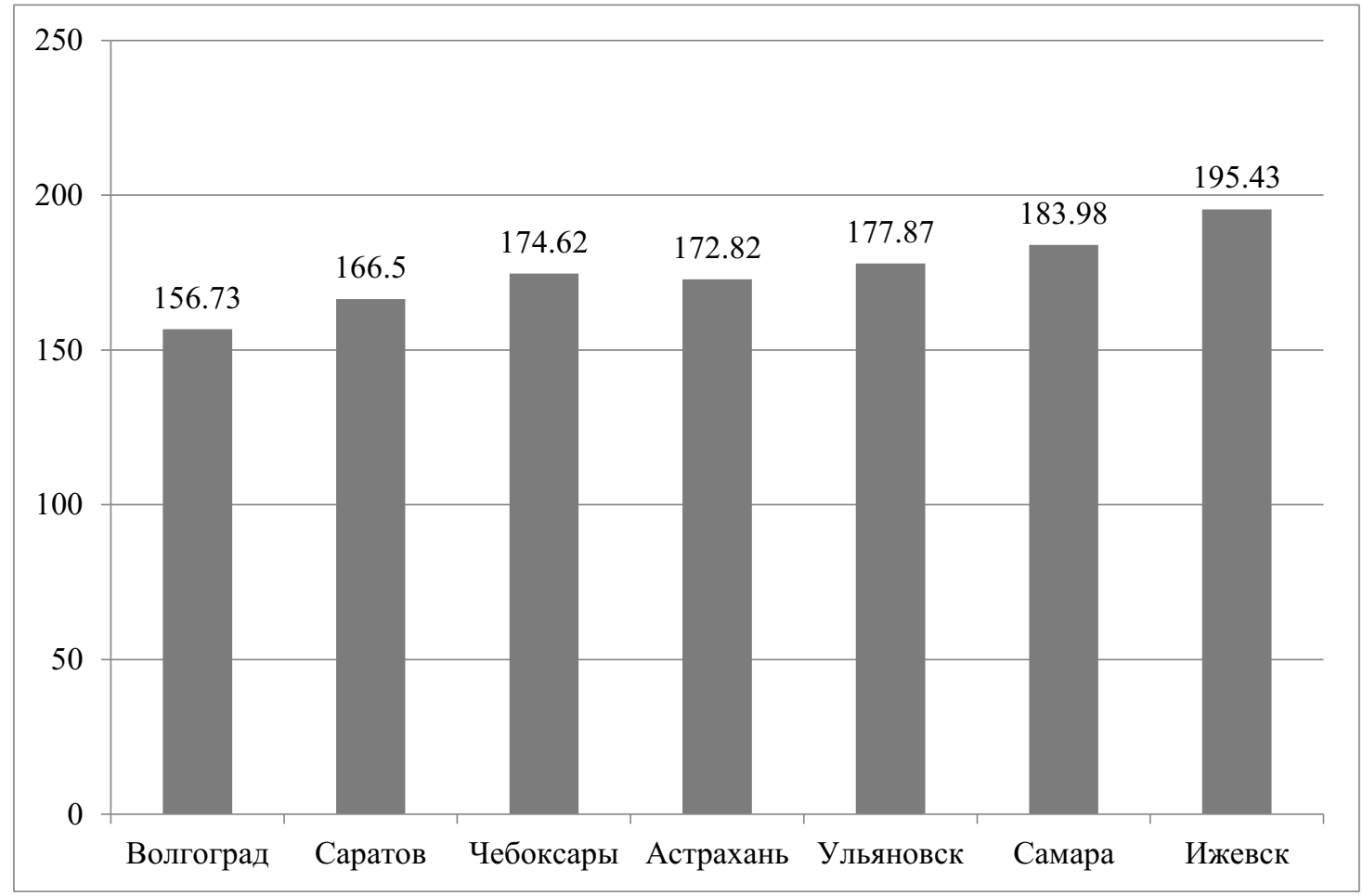

Рис. 3. Дополнительно часов светового дня при переходе с МСК на МСК +1 в 2019 году

Fig. 3. Additionally, daylight hours when switching from MSC to MSC + 1 in 2019

Прирост светового времени позволяет экономить электрическую энергию в первую очередь частным домохозяйствам, а также муниципалитетам на уличном освещении. Однако прирост светового времени и сопутствующая ему экономия электрической энергии будут приходиться только на позднюю весну и лето. В осенне-зимний период прирост на 1 час светового времени во второй половине дня будет скомпенсирован потерей часа светового времени с утра. В зимний период учреждения, работающие с 8.00 до 15.00, а это главным образом образовательные учреждения, теряют световое время. Самые незначительные потери у учреждений Астраханской области - всего 25,57 часа, а самые высокие -в Ульяновской области - 70,28 часа. Чувашская Республика находится северо-западнее Ульяновской области, и переход в зону МСК +1 обернётся для её образовательных учреждений ещё большими потерями светового времени - они достигнут значения 83,72 часа. (рис. 4) Кроме того, следует заметить, что, если скорректировать период бодрствования человека, сместив нижнюю границу с 6.00 до 5.00, то количество дополнительных световых часов в год заметно уменьшится, так в Чувашии их количество упадёт до 120,65 часов [Никонорова, Казаков, 2016а, б; Казаков, Никонорова, 2018; Карасева, Момзикова, 2019].

Задуматься о необходимости перехода Чувашской Республики в зону МСК +1 заставляет также тот факт, что в этом случае в период зимнего солнцестояния (нескольких дней, примыкающих к дню зимнего солнцестояния) время от 6.00 до начала утренних гражданских сумерек (утренней зари) окажется наибольшим во всей часовой зоне, больше чем даже в более западных регионах, Волгоградской, Саратовской областях (рис. 5). 


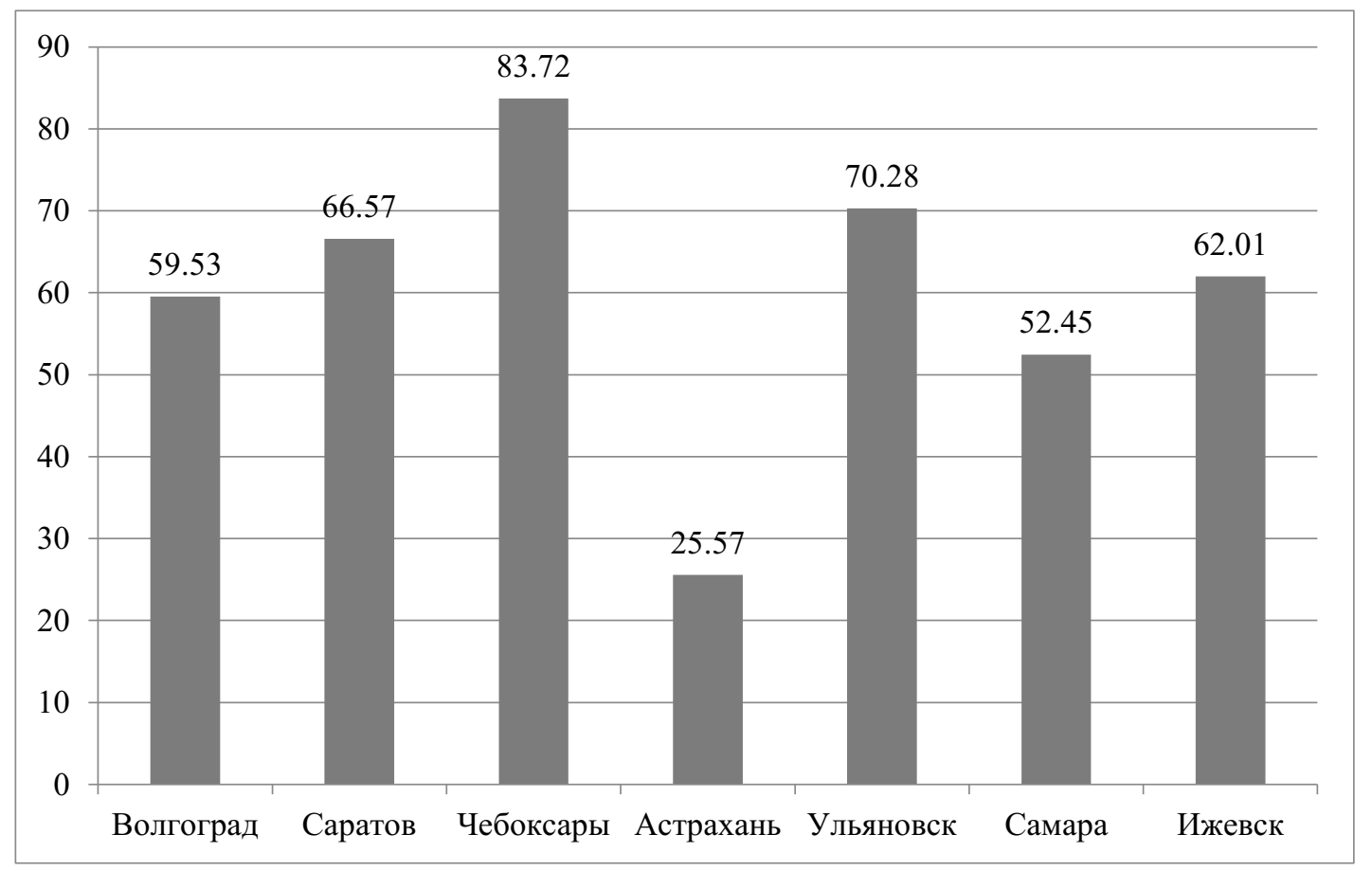

Рис. 4. Потери часов светового дня при переходе с МСК на МСК+1 в 2019 году образовательными учреждениями, работающими в первую смену с 8.00

Fig. 4. Loss of hours of daylight during the transition from MSC to MSC + 1 in 2019 by educational institutions working in the first shift from 8.00

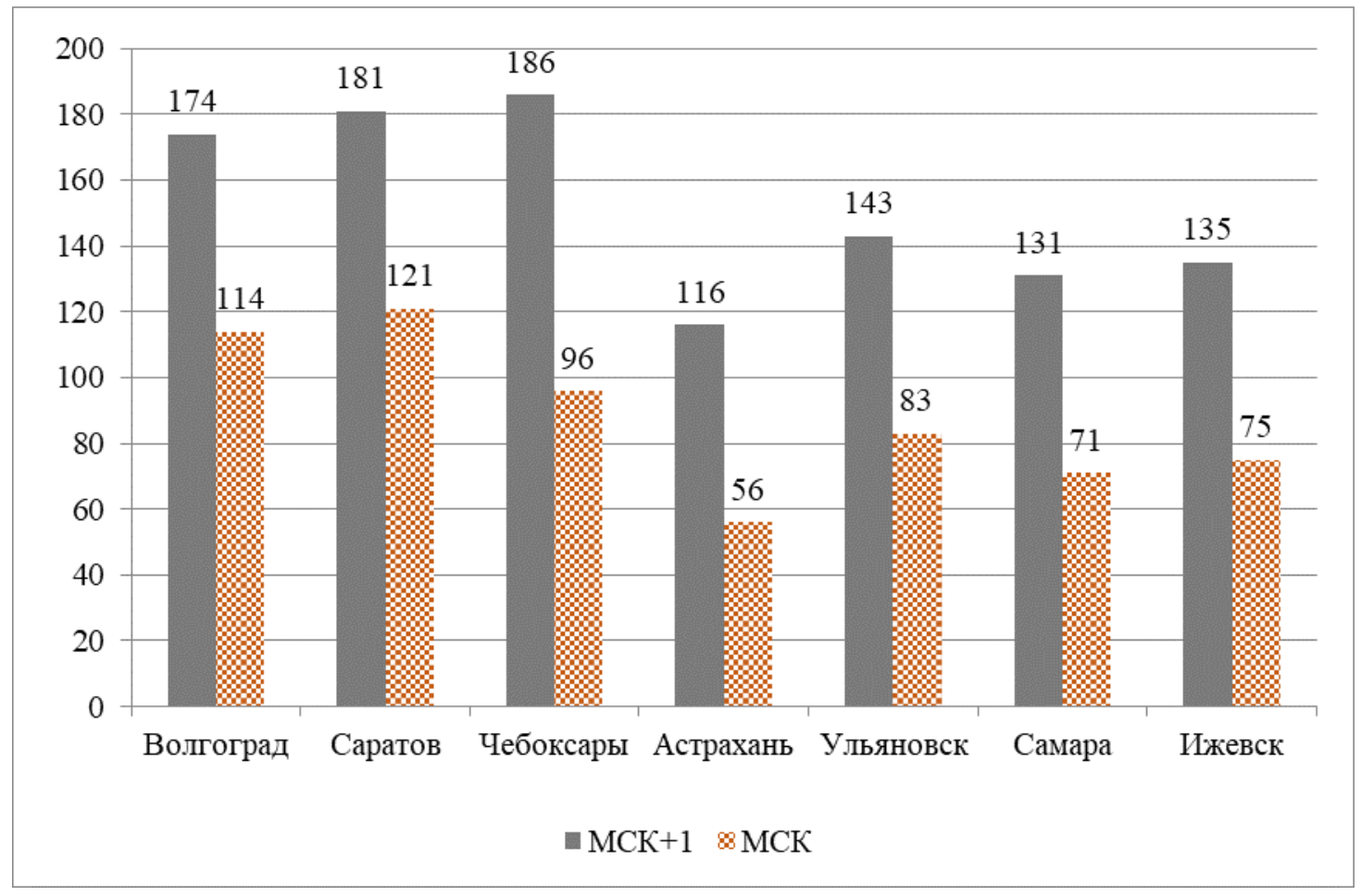

Рис. 5. Время от 6.00 до начала гражданских сумерек (утренней зари) в период зимнего солнцестояния 2019 года, минут

Fig. 5. Time from 6.00 to the beginning of civil twilight (morning dawn) in the winter solstice period of 2019 , minutes. 
Одновременно в период летнего солнцестояния (нескольких дней, примыкающих ко дню летнего солнцестояния) и сегодня в Чувашии (находящейся в зоне МСК) от момента окончания гражданских сумерек (вечерней зари) до 23.00 проходит меньше времени, чем в Астраханской области (находящейся в зоне МСК+1) (рис. 6).

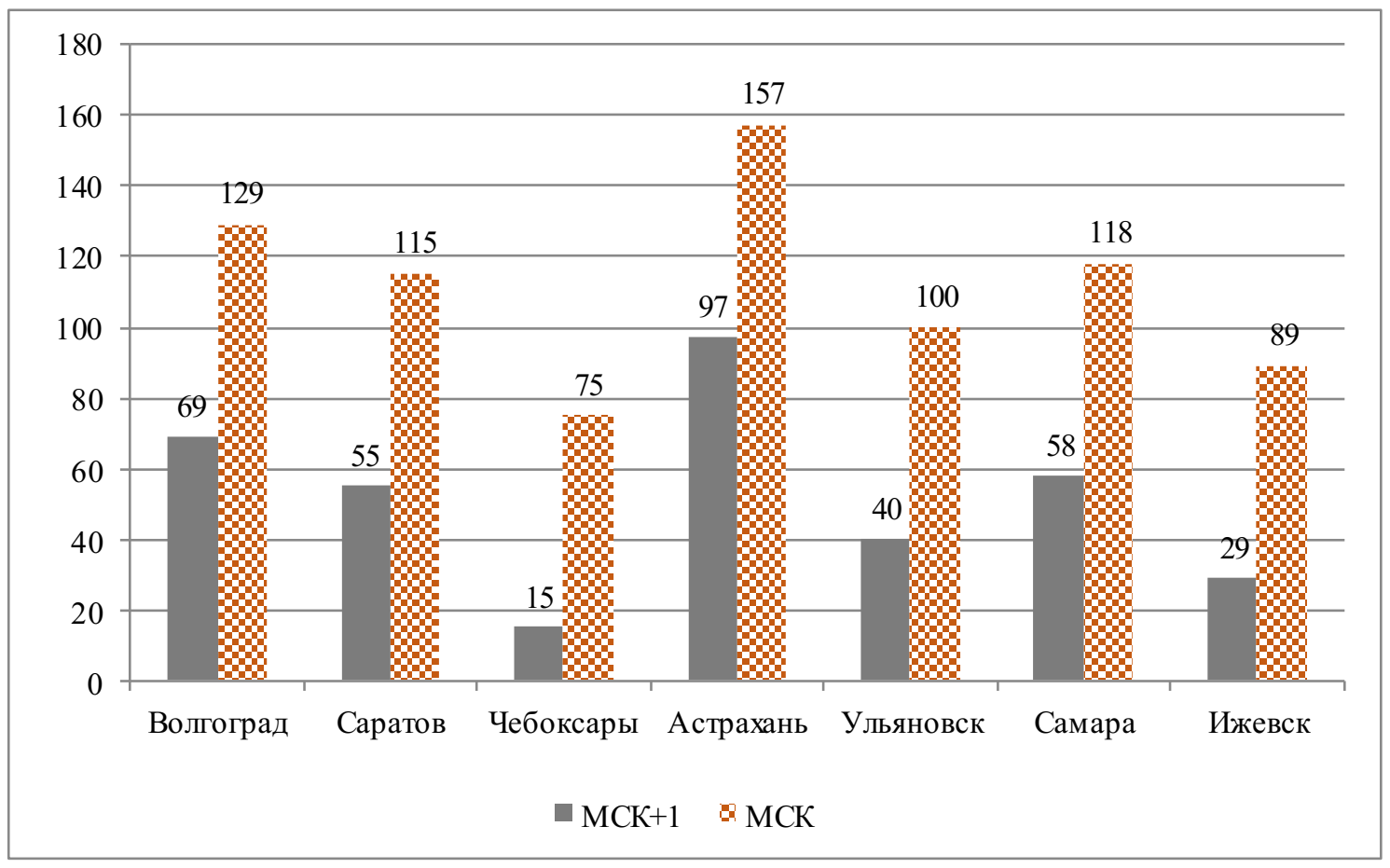

Рис. 6. Время от окончания гражданских сумерек (вечерней зари) до 23 часов в период летнего солнцестояния в 2019 году, минут

Fig. 6. The time from the end of civil twilight (evening dawn) to 23 hours in the period of the summer solstice in 2019 , minutes.

Кроме экономии электрической энергии, увеличение светового времени в период суточного бодрствования людей, по утверждению сторонников перевода стрелок часов на час вперёд, должно привести к снижению уличной преступности и аварийности на дорогах. Обратим внимание на изменение количества некоторых видов преступлений - хулиганства, грабежей, разбойных нападений, изнасилований - в период с 2011 по 2018 год (табл. 2-5) [Количество преступлений, 2019]. В 2015 году в связи с переходом на постоянное «зимнее время» световое время в период суточного бодрствования людей в регионах, продолживших жить по московскому времени (Астраханской, Волгоградской, Саратовской Ульяновской областях и Чувашской Республике), сократилось. Одновременно в Волгоградской, Саратовской областях и Чувашской Республике количество разбойных нападений выросло по сравнению с 2014 годом, в Саратовской области и Чувашской Республике увеличилось количество грабежей, в Волгоградской области - хулиганских действий, в Астраханской и Саратовской областях - изнасилований.

Однако в этот же период, несмотря на потери в световом дне, снизилось количество грабежей и разбойных нападений в Астраханской и Ульяновской областях, изнасилований в Волгоградской, Ульяновской областях и Чувашской Республике, хулиганских действий во всех регионах. В последующем, при переходе в зону МСК +1 и росту используемого светового времени, например, в Саратовской области, снизилось число хулиганских действий, разбойных нападений, но увеличилось число грабежей и изнасилований. Не однозначной была динамика преступлений и в регионах, не испытавших с 2011 года прироста или потери используемого светового времени (табл. 2-5). 
Количество преступлений по ст. 213 УК РФ (хулиганство)

The number of crimes under Art. 213 of the Criminal Code (hooliganism)

\begin{tabular}{|l|c|c|c|c|c|c|c|c|}
\hline \multicolumn{1}{|c|}{ Регион } & 2011 & 2012 & 2013 & 2014 & 2015 & 2016 & 2017 & 2018 \\
\hline Астраханская область & 48 & 42 & 46 & 13 & 12 & 13 & 13 & 20 \\
\hline Волгоградская область & 108 & 119 & 124 & 122 & 117 & 107 & 129 & 79 \\
\hline Удмуртская Республика & 118 & 149 & 136 & 131 & 106 & 107 & 70 & 70 \\
\hline Чувашская Республика & 71 & 85 & 64 & 73 & 46 & 21 & 8 & 13 \\
\hline Самарская область & 125 & 132 & 101 & 56 & 50 & 26 & 30 & 21 \\
\hline Саратовская область & 43 & 35 & 45 & 27 & 18 & 15 & 11 & 10 \\
\hline \multicolumn{2}{|l|}{} \\
\hline
\end{tabular}

Таблица 3

Table 3

Количество преступлений по ст. 162 УК РФ (разбой)

The number of crimes under Art. 162 of the Criminal Code (thuggery)

\begin{tabular}{|l|c|c|c|c|c|c|c|c|}
\hline \multicolumn{1}{|c|}{ Регион } & 2011 & 2012 & 2013 & 2014 & 2015 & 2016 & 2017 & 2018 \\
\hline Астраханская область & 151 & 118 & 109 & 70 & 68 & 60 & 53 & 52 \\
\hline Волгоградская область & 252 & 262 & 260 & 214 & 221 & 169 & 168 & 149 \\
\hline Удмуртская Республика & 225 & 196 & 195 & 168 & 173 & 116 & 109 & 67 \\
\hline Чувашская Республика & 119 & 105 & 73 & 50 & 67 & 49 & 33 & 18 \\
\hline Самарская область & 669 & 481 & 345 & 282 & 266 & 244 & 208 & 154 \\
\hline Саратовская область & 192 & 163 & 158 & 145 & 149 & 122 & 77 & 95 \\
\hline Ульяновская область & 201 & 185 & 194 & 145 & 120 & 126 & 91 & 79 \\
\hline & \multicolumn{10}{|l|}{$\begin{array}{l}\text { количесвво преступлений в периоды уменьшения и увеличения использу- } \\
\text { емого светового времени в течение года }\end{array}$} \\
\hline
\end{tabular}

Таблица 4

Table 4

Количество преступлений по ст. 161 УК РФ (грабёж)

The number of crimes under Art. 161 of the Criminal Code (robbery)

\begin{tabular}{|l|c|c|c|c|c|c|c|c|}
\hline \multicolumn{1}{|c|}{ Регион } & 2011 & 2012 & 2013 & 2014 & 2015 & 2016 & 2017 & 2018 \\
\hline Астраханская область & 952 & 770 & 592 & 475 & 440 & 402 & 328 & 334 \\
\hline Волгоградская область & 2169 & 2097 & 1709 & 1463 & 1462 & 1228 & 1397 & 1340 \\
\hline Удмуртская Республика & 2084 & 1635 & 1407 & 1219 & 1018 & 777 & 824 & 779 \\
\hline Чувашская Республика & 865 & 756 & 536 & 423 & 441 & 294 & 338 & 234 \\
\hline Самарская область & 4461 & 3692 & 2353 & 2035 & 1423 & 1251 & 1243 & 1102 \\
\hline Саратовская область & 1721 & 1290 & 933 & 882 & 905 & 662 & 677 & 690 \\
\hline Ульяновская область & 922 & 783 & 650 & 590 & 506 & 528 & 377 & 413 \\
\hline &
\end{tabular}




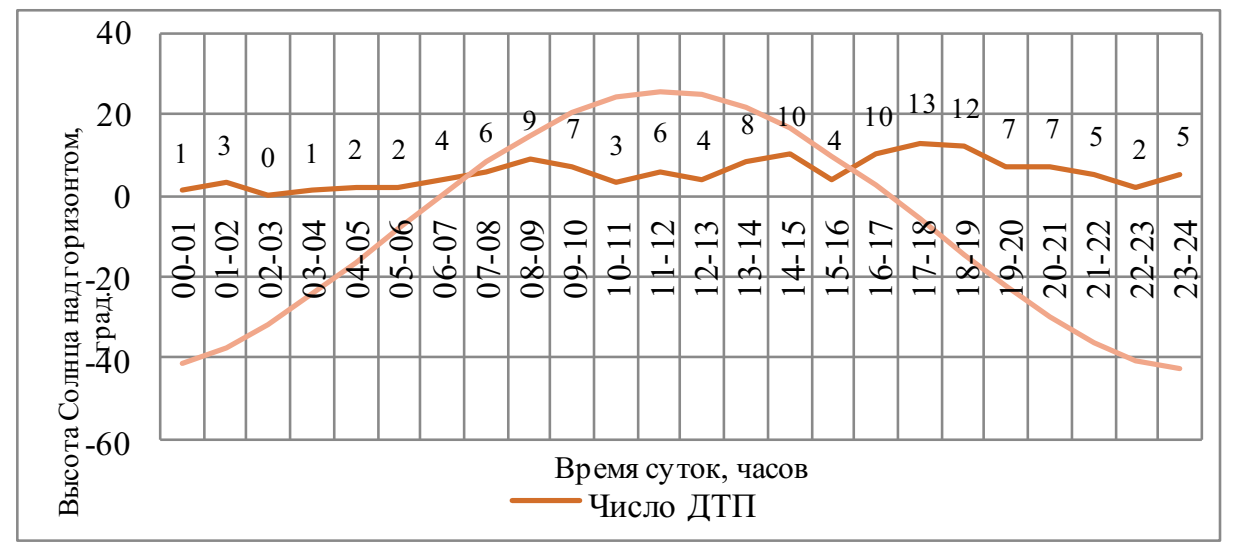

Рис. 7. Накопленное количество ДТП за месяц и высота Солнца над горизонтом в октябре 2018 года в Чувашии

Fig. 7. The accumulated quantity of accidents per month and the height of the Sun above the horizon in October 2018 in Chuvashia

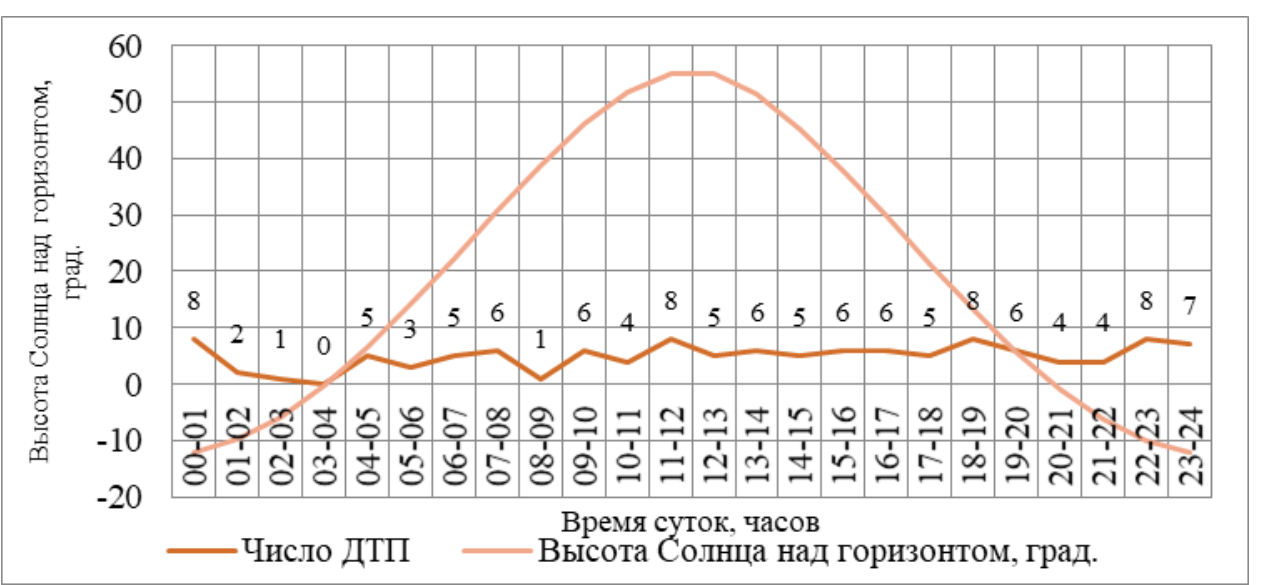

Рис. 8. Накопленное количество ДТП за месяц и высота Солнца над горизонтом в июле 2018 года в Чувашии

Fig. 8. The accumulated quantity of accidents per month and the height of the Sun above the horizon in July 2018 in Chuvashia

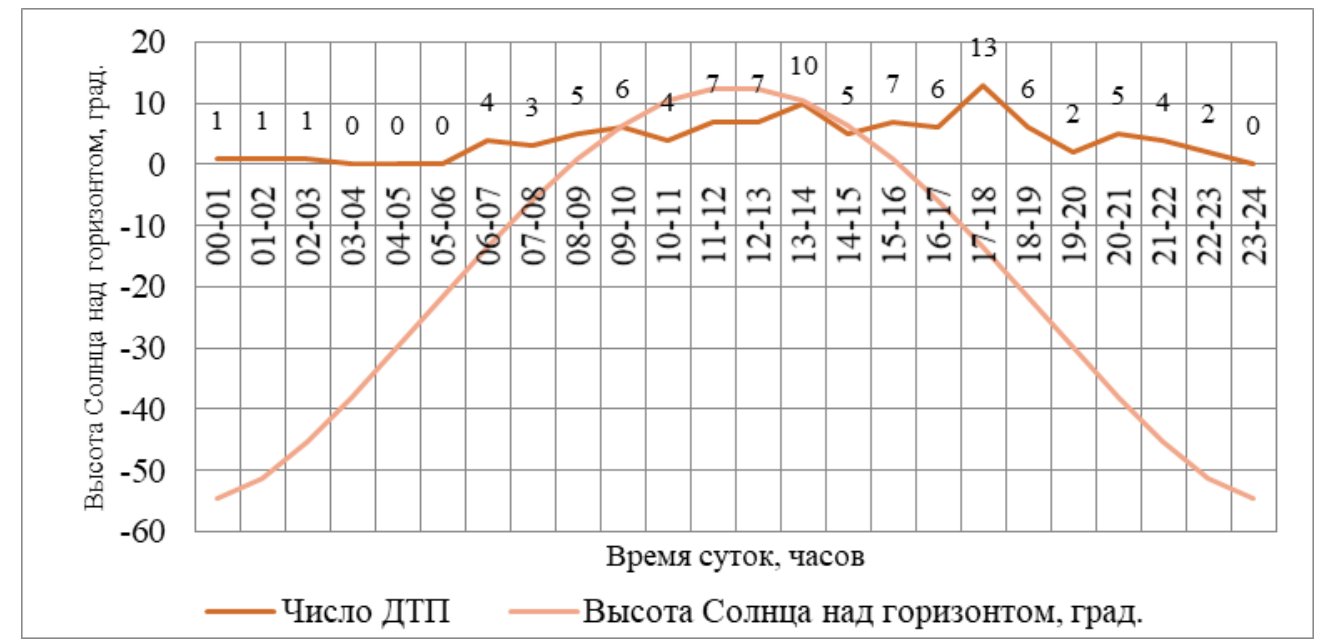

Рис. 9. Накопленное количество ДТП за месяц и высота Солнца над горизонтом в январе 2019 года в Чувашии

Fig. 9. The accumulated quantity of accidents per month and the height of the Sun above the horizon in January 2019 in Chuvashia 
Но полностью принять данный вывод мешает наблюдающаяся в первой половине светового дня прямая зависимость количества ДТП от высоты стояния Солнца над горизонтом, то есть чем выше Солнце, тем больше ДТП. Прямая зависимость количества ДТП от высоты Солнца над горизонтом в первой половине дня наблюдалась также в июле (значение корреляционной связи 0,38$)$ и особенно она сильна была в январе 2018 года $(0,84)$. В июле 2018 года значение корреляционной связи в период от полудня до окончания гражданских сумерек составило 0,2 (по сути, связь отсутствовала), а в январе - 0,43 (связь была прямой?). Скорее всего, количество ДТП не столько связано с движением Солнца по небосводу, сколько с суточным изменением интенсивности потока автотранспортных средств на дорогах республики.

\section{Выводы}

Таким образом, отказ рассмотренных регионов от жизни по московскому времени после 2014 года привёл к увеличению среднеквадратичного отклонения времени наступления истинного полдня от полдня по местному времени, за исключением Удмуртской Республики, однако положительно скорректировал границы светового дня в весенне-летний период со средними границами времени бодрствования людей, что должно было привести к некоторой экономии электрической энергии. Существенного влияния на криминогенную обстановку и аварийность на дорогах перевод стрелок на час вперёд не оказал.

В случае перехода в часовую зону МСК+1 Чувашской Республики она также приобретёт дополнительные часы светового дня в весенне-летний период, но из-за крайнего северо-западного положения в зоне её образовательные учреждения, работающие в первую смену, понесут наибольшие потери в часах светового дня в осенне-зимний период.

Заставляет сомневаться в необходимости перехода Чувашской Республики в зону МCК+1 и то, что в окружающих её регионах, исключая Ульяновскую область, непосредственно граничащую с республикой лишь на крайнем юго-западе, сохраняется московское время. Возникнет дополнительный преодолимый, но не нужный временной барьер в социально-экономическом взаимодействии Чувашии (движении информационных, людских, материальных, финансовых потоков) с сопредельными регионами и Москвой.

Так, при движении транзитных транспортных потоков, особенно автомобильных по трассам М-7, Р-176 «Вятка» и даже А-151 перевозчикам придётся брать в расчёт колебания местного времени при пересечении границ Чувашской Республики. Учитывать эти колебания придётся и организаторам речных туристских круизов по Волге. Потребуется постоянная корреляция режима работы органов власти Чувашской Республики с временем работы администрации полномочного представителя Президента России в ПФО, Правительством Российской Федерации, а также федеральными министерствами и ведомствами.

Испытают неудобство жители Чувашии, регулярно посещающие Татарстан, Марий Эл, Мордовию, Нижегородскую область или другие регионы часовой зоны МСК. Разница во времени скажется даже при общении в социальных сетях с жителями данных регионов. Поэтому ставить вопрос о переходе Чувашии в часовую зону МСК+1 при не столь выраженных преимуществах в сравнении с другими рассмотренными нами регионами следует лишь после того, когда хотя бы крупный восточный сосед Чувашии - Республика Татарстан сделает подобный шаг.

\section{Список использованных источников}

1. Количество дорожно-транспортных происшествий с пострадавшими. Электронный реcypc. URL: https://fedstat.ru/indicator/36234 (дата обращения: 19 августа 2019).

2. Количество преступлений зарегистрированных в отчётном периоде. Электронный реcypc. URL: https://fedstat.ru/indicator/36225 (дата обращения: 19 августа 2019). 
3. Официальный сайт ГИБДД МВД России. Сведения о показателях состояния безопасности дорожного движения. Электронный ресурc. URL: http://stat.gibdd.ru (Дата обращения 30 апреля 2019).

4. О составе территорий, образующих каждую часовую зону, и порядке исчисления времени в часовых зонах, а также о признании утратившими силу отдельных Постановлений Правительства Российской Федерации: Постановление Правительства РФ от 31.08.2011 № 725 // СПС Консультант Плюс. URL: http://www.consultant.ru/document/cons_doc_LAW_118896/ (дата обращения: 19 августа 2019).

5. Об исчислении времени: Федеральный закон от 03.06.2011 № 107-Ф3 // СПС Консультант Плюс. URL: http://www.consultant.ru/document/cons_doc_LAW_114656/ (дата обращения: 19 августа 2019).

\section{Список литературы}

1. Алексеев В.Б., Лебедева-Несевря Н.А., Барг А.О., Гасников В.К. 2012. Медикосоциальные риски десинхронизации административного и астрономического времени в оценках населения регионов России. Социальные аспекты здоровья населения, 5 (27): 1-10.

2. Ермолаев А.И. 2016. Государственное регулирование суточного времени в России в XX в. Российская история, 5: 161-163.

3. Звоновский В.Б. 2010. Московское время и российские пространства. Социологическое обозрение, 9 (3): 51-56.

4. Звягина Е.В., Диогенова К.С. 2018. Влияние факторов режима дня на здоровье студентов, занимающихся спортом. Здоровье человека, теория и методика физической культуры и спорта, 4 (11): 37-48.

5. Казаков Н.А., Никонорова И.В. 2018. Возвращаясь к вопросу о времени ... Материалы докладов региональной научно-практической конференции. Чебоксары, рекламнополиграфическое бюро «Плакат»: 46-47.

6. Карасева А.И., Момзикова М.П. 2019. Часовые пояса и синхронные телекоммуникации: незаметная работа по темпоральной координации у горожан Дальнего Востока. Этнографическое обозрение, 3: 42-61.

7. Никонорова И.В., Казаков Н.А. 2016а. К вопросу об изменении исчисления времени в Чувашии. Материалы Всероссийской молодежной школы-конференции. Чебоксары, ЦНС «Интерактив-плюс»: 279-285.

8. Никонорова И.В., Казаков Н.А. 2016б. И вновь о времени... Материалы докладов региональной научно-практической конференции. Чебоксары, рекламно-полиграфическое бюро «Плакат»: 95-101.

9. Цфасман А.З., Горохов В.Д., Алпаев Д.В. 2013. Суточный ритм мелатонина при депривации ночного сна. Проблемы эндокринологии, 59 (2): 40-44.

10.Kotlyakov V.M., Komarova A.I. 2007. Elsevier's dictionary of geography: In English, Russian, French, Spanish and German. Moscow, Elsevier, 1073 p.

\section{References}

1. Alekseev V.B., Lebedeva-Nessevrya N.A., Barg A.O., Gasnikov V.K. 2012. Medical and social risks of desynchronization of administrative and astronomical time in estimates of the population of Russian regions. Social aspects of public health, 5 (27): 1-10. (in Russian)

2. Ermolaev A.I. 2016. State regulation of daily time in Russia in the XX century. Russian history, 5: 161-163. (in Russian) Russian)

3. Zvonovsky V.B. 2010. Moscow time and Russian space. Sociological review, 9 (3): 51-56. (in

4. Zvyagina E.V., Diogenova K.S. 2018. The influence of daily regime factors on the health of students involved in sports. Human Health, Theory and Methods of Physical Culture and Sports, 4 (11): 37-48. (in Russian) 
5. Kazakov N.A., Nikonorova I.V. 2018. Returning to the question of time ... Materials of reports of a regional scientific-practical conference. Cheboksary, advertising and printing bureau "Poster": 46-47. (in Russian)

6. Karaseva A.I., Momzikova M.P. 2019. Time zones and synchronous telecommunications: inconspicuous work on temporal coordination among the citizens of the Far East. Ethnographic Review, 3: 42-61. (in Russian)

7. Nikonorova I.V., Kazakov N.A. 2016a. To the question of changing the calculation of time in Chuvashia. Materials of All-Russian youth school conference. Cheboksary, Central nervous system Interactive Plus: 279-285. (in Russian)

8. Nikonorova I.V., Kazakov N.A. 2016b. And again about the time ... Materials of reports of the regional scientific-practical conference. Cheboksary, advertising and printing bureau "Poster": 95-101. (in Russian)

9. Tsfasman A.Z., Gorokhov V.D., Alpaev D.V. 2013. The daily rhythm of melatonin in the deprivation of night sleep. Problems of endocrinology, 59 (2): 40-44. (in Russian)

10. Kotlyakov V.M., Komarova A.I. 2007. Elsevier's dictionary of geography: In English, Russian, French, Spanish and German. Moscow, Elsevier, 1073 p.

\section{ИНФОРМАЦИЯ ОБ АВТОРАХ}

Архипов Ю.Р., профессор, доктор географических наук, заведующий кафедрой экономической и социальной географии Чувашского государственного университета имени И.Н. Ульянова, г. Чебоксары, Россия

Никонорова И.В., доцент, кандидат географических наук, заведующая кафедрой физической географии и геоморфологии Чувашского государственного университета имени И.Н. Ульянова, г. Чебоксары, Россия

Казаков Н.А., кандидат географических наук, доцент, заместитель заведующего кафедрой экономической и социальной географии, заместитель декана историко-географического факультета Чувашского государственного университета имени И.Н. Ульянова, г. Чебоксары, Россия

Караганова Н.Г., старший преподаватель кафедры природопользования и геоэкологии Чувашского государственного университета имени И.Н. Ульянова, г. Чебоксары, Россия

\section{INFORMATION ABOUT THE AUTHOR}

Yury R. Arkhipov, professor, doctor of geographical Sciences, head of the Department of economic and social geography of Chu-Vash state University named after I.N. Ulyanov, Cheboksary, Russia

Inna V. Nikonorova, associate Professor, candidate of geographical Sciences, head of the Department of physical geography and geomorphology of the I. N. Ulyanov Chuvash state University named after I. N. Ulyanov,, Cheboksary, Russia

Nikolay A. Kazakov, candidate of geographical Sciences, associate Professor, Deputy head of the Department of economic and social geography, Deputy Dean of the faculty of history and geography of the Chuvash state University named after I. N. Ulyanov, Cheboksary, Russia

Natalia G. Karaganova, senior lecturer at the Department of environmental management and Geoecology of the I. N. Ulyanov Chuvash state University, Cheboksary, Russia 